\title{
Fungal Metabolites, Sorbicillinoid Polyketides and Their Effects on the Activation of Peroxisome Proliferator-activated Receptor $\gamma$
}

\author{
Dongho Lee, Jeong Hyung Lee, Xing Fu Cai, Jin Chul Shin, Kyeong Lee, \\ Young-Soo Hong, Jung Joon Lee
}

Received: June 22, 2005 / Accepted: October 4, 2005

(C) Japan Antibiotics Research Association

\begin{abstract}
A new sorbicillinoid polyketide, dihydrotrichodimerol (2), along with known trichodimerol (1), and rezishanones C (3) and D (4) were isolated by bioassay-guided fractionation from an unidentified fungal strain. Dihydrotrichodimerol (2) specifically activated peroxisome proliferator-activated receptor $\gamma$ with an $\mathrm{ED}_{50}$ value of $80 \mathrm{ng} / \mathrm{ml}$ as measured by a transactivation assay using a chimeric hPPAR/GAL4 system without affecting peroxisome proliferator-activated receptors $\alpha$ and $\delta$. On the other hand, compounds $\mathbf{1}$ and $\mathbf{2}$ suppressed the production of tumor necrosis factor- $\alpha$ and nitric oxide in LPSstimulated RAW264.7 cells to a similar extent.
\end{abstract}

Keywords sorbicillinoid, trichodimerol derivative, peroxisome proliferator-activated receptor $\gamma$, tumor necrosis factor- $\alpha$, nitric oxide

\section{Introduction}

Peroxisome proliferator-activated receptors (PPARs) are members of the nuclear receptor superfamily of ligandactivated transcription factors, a family that includes the receptors for steroid hormones, retinoids, thyroid hormone, and vitamin $\mathrm{D}$. Three mammalian PPARs have been identified to date, termed $\operatorname{PPAR} \alpha, \operatorname{PPAR} \gamma$, and $\operatorname{PPAR} \delta$.
PPARs function as regulators of lipid and lipoprotein metabolism, glucose homeostasis, cellular differentiation and also appear to control the inflammatory response $[1,2]$. PPAR $\gamma$ agonists have therapeutic potential in the treatment of type 2 diabetes, inflammatory disease, and certain cancers [3].

In our search for biologically active agents of natural origin, the culture broth of an unidentified fungal strain exhibited significant activity in a reporter gene assay of peroxisome proliferator-activated receptor $\gamma(\operatorname{PPAR} \gamma)$ [4]. Bioassay-guided fractionation of an EtOAc-soluble extract of fungus using this assay resulted in the isolation of a new sorbicillinoid polyketide, dihydrotrichodimerol (2), as well as three known sorbicillinoids, trichodimerol (1), and rezishanones C (3) and D (4) (Fig. 1) [5 7]. Sorbicillinoid polyketides, unique metabolites from various terrestrial and marine fungi, have drawn recent interest in terms of their structural complexity and biological activity including antioxidant and tumor necrosis factor (TNF)- $\alpha$ inhibitory activities [5, 8 11]. Synthetic and biosynthetic studies of trichodimerol (1) and related natural products have been reported by several groups [12 16]. Here we described the isolation, structural characterization of compounds $\mathbf{1} \sim \mathbf{4}$ and the biological evaluation of the compounds isolated.
J. J. Lee (Corresponding author), D. Lee, J. H. Lee, X. F. Cai, J. C. Shin, K. Lee, Y.-S. Hong: Anticancer Research Laboratory, Korea Research Institute of Bioscience and Biotechnology, P.O. Box 115, Yuseong, Daejeon 305-600, Korea.

E-mail: jjlee@kribb.re.kr

\footnotetext{
${ }^{\dagger}$ The same new compound (dihydrotrichodimerol) which was isolated independently appears in this issue (pages 621 624).
} 


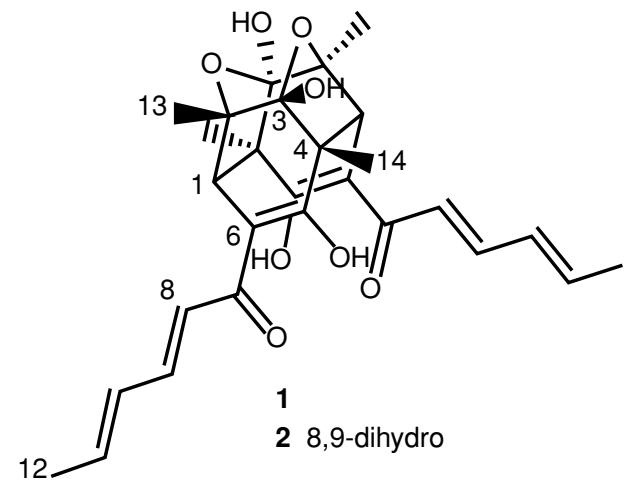

Fig. 1 Structures of compounds $\mathbf{1} \sim \mathbf{4}$.

\section{Materials and Methods}

\section{General Experimental Procedure}

All melting points were determined on an Electrothermal 9100 instrument without correction. Optical rotations were measured on a JASCO P-1020 polarimeter. UV and CD spectra were measured on a Shimadzu UV-1601 UV-visible and a JASCO J-7200 spectrophotometers, respectively. NMR spectra were recorded on Varian UNITY 400 or Bruker DMX 600 NMR spectrometers with $\mathrm{CDCl}_{3}$. ESIMS and HRESI-MS were obtained on a Platform quadrupole and Mariner mass spectrometers, respectively. HRFAB-MS was obtained on a JMS-HX110A/HX110A Tandem Mass spectrometer (JEOL). Preparative and recycling HPLC were carried out on a Waters semi-prep and LC-908 Japan Analytical systems, respectively.

\section{Fermentation}

An unidentified fungal strain B00853 isolated from a soil sample collected in a field in Yuseong, Daejeon, was cultured in a seed agar medium, which was composed of glucose $2 \%$, malt extract $2 \%$, peptone $0.1 \%$, agar $1.8 \%$. The production medium was composed of soluble starch $2.2 \%$, yeast extract $0.2 \%$, polypeptone $0.5 \%, \mathrm{MgSO}_{4}$. $7 \mathrm{H}_{2} \mathrm{O} 0.05 \%$ and $\mathrm{KH}_{2} \mathrm{PO}_{4} 0.1 \%$ and adjusted to $\mathrm{pH}$ 5.6. For production cultures, $300 \mathrm{ml}$ of production medium in 1000$\mathrm{ml}$ baffled flasks was inoculated with $1 \times 1 \mathrm{~cm}$ seed agar piece of fully grown mycelia of the fungus, and the flasks were incubated at $28^{\circ} \mathrm{C}$ and $180 \mathrm{rpm}$ for 7 days.

\section{Bioassay for Activation of Peroxisome Proliferator- Activated Receptors}

The ligand binding domains (LBDs) of hPPAR $\alpha$ (amino acids $167 \sim 468$ ), hPPAR $\delta$ (amino acids $167 \sim 441$ ), and hPPAR $\gamma$ (amino acids $163 \sim 477$ ) were generated by PCR amplification using $P f u$ polymerase (Stratagene, La Jolla, CA, USA) and gene specific primers flanked with

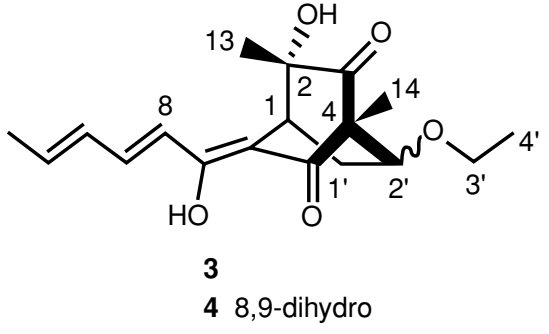

restriction enzymes $B a m \mathrm{HI}$ and $X b a \mathrm{I}$, respectively. The LBDs were subcloned in-frame into the pFA-CMV (Stratagene, La Jolla, CA, USA) vector. The 4xGAL4luciferase reporter plasmid ( $\mathrm{pFR}-\mathrm{Luc}$ ) was from Stratagene. The ability of the compound to activate PPARs was determined by a transactivation assay. The pFA-GAL4PPARs chimera expression constructs, containing the LBD of human PPARs, were prepared by standard methods for the vector. At $75 \sim 90 \%$ confluence, NIH3T3 cells were transiently co-transfected with the vectors for pFA-GAL4PPAR, pFR-Luc and pRL-CMV (Promega, Madison, WI, USA) using Lipofectamine plus reagent according to the instructions of manufacturer (Invitrogen). Following 24 hours incubation, the cells were treated with various concentrations of the test compounds and incubated for 16 hours. Luciferase assay was performed using a Dualluciferase reporter assay system according to the instructions of the manufacturer (Promega). Luciferase activity was determined in a Microlumat Plus luminometer (EG\&G Berthold, Bad Wildbad, Germany) by injecting $100 \mu \mathrm{l}$ of assay buffer containing luciferin and measuring light emission for 10 seconds. The results were normalized to the activity of Renilla expressed by cotransfected Rluc gene under the control of a constitutive promoter $[4,17]$.

\section{Bioassay of Nitric Oxide Production}

RAW264.7 cells were seeded in 96 well plates at $1 \times 10^{5}$ cells/well. After 3 hours, the cells were treated with various concentrations of compounds and stimulated for 24 hours with or without $1 \mu \mathrm{g} / \mathrm{ml}$ of LPS (Sigma Chemical Co., St. Louis, MO, USA). As a parameter of nitric oxide (NO) synthesis, nitrite concentration was measured in the supernatant of RAW264.7 cells by the Griess reaction as previously described [18].

\section{Bioassay of TNF- $\alpha$ Production}

RAW264.7 cells were seeded in 96 well plates at a 
density of $1 \times 10^{4}$ cells/well, pretreated with different concentrations of compounds for 1 hours; then the cells were stimulated with LPS $(1 \mu \mathrm{g} / \mathrm{ml})$ for 18 hours. TNF- $\alpha$ production in the supernatant of RAW264.7 cells was quantitated using OptELATM assay kit according to the manufacture's instructions (Pharmingen, San Diego, CA, USA) as previously described [18].

\section{Results and Discussion}

\section{Isolation and Characterization of Fungal Metabolites}

An unidentified fungal strain was grown in 8 liters liquid media at $28^{\circ} \mathrm{C}$ for 7 days. The cultured broth was extracted with EtOAc twice and these extracts were filtered through a fritted funnel in vacuo to remove insolubles. The volume of the filtrate was reduced in vacuo and then partitioned between EtOAc and $\mathrm{H}_{2} \mathrm{O}$ to give the organic extracts $(2.6 \mathrm{~g})$. Fractionation of the EtOAc-soluble extract was initiated by silica gel chromatography using a $\mathrm{CHCl}_{3}$ $\mathrm{MeOH}$ gradient as mobile phase, and fractions obtained were pooled based on TLC and ESI-MS analysis. Fraction
1, eluted with $\mathrm{CHCl}_{3}-\mathrm{MeOH}(99: 1)$, was passed through a Sephadex LH-20 column using $\mathrm{CHCl}_{3}-\mathrm{MeOH}(1: 1)$ and further purified by recycling HPLC [YMC ODS-A, $250 \times 20 \mathrm{~mm}$ i.d., $50 \% \mathrm{MeCN}-\mathrm{H}_{2} \mathrm{O}(0.05 \% \mathrm{TFA}), 10 \mathrm{ml} /$ minute] to afford compound $3(2.7 \mathrm{mg}, 0.10 \% \mathrm{w} / \mathrm{w})$ and compound 4 (3.6 mg, 0.14\% w/w). Fraction 4, eluted with $\mathrm{CHCl}_{3}-\mathrm{MeOH}(50: 1)$, was passed through a Sephadex LH-20 column using $\mathrm{CHCl}_{3}-\mathrm{MeOH}(1: 1)$ and further purified by HPLC [YMC ODS-A, $250 \times 20 \mathrm{~mm}$ i.d., $\mathrm{MeCN}$ $\mathrm{H}_{2} \mathrm{O}(0.05 \%$ TFA $)$ gradient, $10 \mathrm{ml} /$ minute] to afford compound $1(5.8 \mathrm{mg}, 0.22 \% \mathrm{w} / \mathrm{w})$ and compound 2 (9.8 mg, $0.38 \% \mathrm{w} / \mathrm{w})$.

Trichodimerol (1)

Yellow powder; mp $140 \sim 142^{\circ} \mathrm{C} ;[\alpha]_{\mathrm{D}}-387^{\circ}$ (c 0.05 , $\mathrm{MeOH}), \mathrm{UV}(\mathrm{MeOH}): \lambda_{\max }(\log \varepsilon) 242$ (3.94), 359 (4.49) $\mathrm{nm} ; \mathrm{CD}(\mathrm{MeOH}) \lambda_{\max }(\Delta \varepsilon) 281(-3.0), 342(+1.6), 383$ $(-4.1) ;{ }^{1} \mathrm{H}$ and ${ }^{13} \mathrm{C}$ NMR data, see Tables 1 and 2; ESI-MS $\mathrm{m} / \mathrm{z} 519[\mathrm{M}+\mathrm{Na}]^{+}, 495[\mathrm{M}-\mathrm{H}]^{-}$.

Dihydrotrichodimerol (2)

Yellow powder; $\mathrm{mp} 82 \sim 83^{\circ} \mathrm{C} ;[\alpha]_{\mathrm{D}}+99^{\circ}($ c $0.01, \mathrm{MeOH})$, UV (MeOH): $\lambda_{\max }(\log \varepsilon) 309$ (4.19), 361 (4.31) nm; CD $(\mathrm{MeOH}) \lambda_{\max }(\Delta \varepsilon) 282(-3.9), 385(-0.5) ;{ }^{1} \mathrm{H}$ and ${ }^{13} \mathrm{C}$

Table $1{ }^{1}$ H NMR data of compounds $\mathbf{1} \sim \mathbf{4 .}$

\begin{tabular}{|c|c|c|c|c|}
\hline No. & 1 & 2 & 3 & 4 \\
\hline 1 & $2.99 \mathrm{~s}$ & $2.92 \mathrm{~s}$ & $3.15 \mathrm{t}(2.4)$ & $3.05 t(2.8)$ \\
\hline 8 & $6.13 d(15.0)$ & $2.38 \mathrm{~m}, 2.45 \mathrm{~m}$ & $6.20 \mathrm{~m}$ & $2.45 \mathrm{~m}$ \\
\hline 9 & $7.31 \mathrm{dd}(10.2,14.7)$ & $2.27 \mathrm{~m}$ & $7.29 \mathrm{dd}(10.4,14.8)$ & $2.35 \mathrm{~m}$ \\
\hline 10 & $6.28 \mathrm{~m}$ & $5.42 \mathrm{~m}$ & $6.26 \mathrm{~m}$ & $5.49 \mathrm{~m}$ \\
\hline 11 & $6.22 \mathrm{~m}$ & $5.49 \mathrm{~m}$ & $6.21 \mathrm{~m}$ & $5.44 m$ \\
\hline 12 & $1.88 d(5.7)$ & $1.64 d(6.0)$ & $1.89 \mathrm{~d}(6.8)$ & $1.64 d(6.4)$ \\
\hline 13 & $1.42 \mathrm{~s}$ & $1.42 \mathrm{~s}$ & $1.21 \mathrm{~s}$ & $1.22 \mathrm{~s}$ \\
\hline 14 & $1.45 \mathrm{~s}$ & $1.44 \mathrm{~s}$ & $1.32 \mathrm{~s}$ & $1.31 \mathrm{~s}$ \\
\hline \multirow[t]{2}{*}{$1^{\prime}$} & & $2.98 \mathrm{~s}$ & $1.68 \mathrm{dt}(2.8,13.6)$ & $1.61 \mathrm{~m}$ \\
\hline & & & $2.79 \mathrm{ddd}(2.0,8.0,13.6)$ & $2.77 \mathrm{ddd}(2.0,7.6,13.6)$ \\
\hline $2^{\prime}$ & & & $3.56 \mathrm{~m}$ & $3.53 \mathrm{~m}$ \\
\hline $3^{\prime}$ & & & $3.36 \mathrm{~m}, 3.55 \mathrm{~m}$ & $3.37 \mathrm{~m}, 3.55 \mathrm{~m}$ \\
\hline $4^{\prime}$ & & & $1.12 \mathrm{t}(6.8)$ & $1.13 t(6.8)$ \\
\hline $8^{\prime}$ & & $6.14 \mathrm{~d}(14.4)$ & & \\
\hline $9^{\prime}$ & & $7.32 \mathrm{dd}(10.8,15.0)$ & & \\
\hline $10^{\prime}$ & & $6.29 \mathrm{~m}$ & & \\
\hline $11^{\prime}$ & & $6.20 \mathrm{~m}$ & & \\
\hline $12^{\prime}$ & & $1.88 d(6.6)$ & & \\
\hline $13^{\prime}$ & & $1.42 \mathrm{~s}$ & & \\
\hline $14^{\prime}$ & & $1.43 \mathrm{~s}$ & & \\
\hline $5-\mathrm{OH}$ & $16.34 \mathrm{~s}$ & $16.54 \mathrm{~s}$ & & \\
\hline $7-\mathrm{OH}$ & & & $14.0 \mathrm{~s}$ & $14.3 \mathrm{~s}$ \\
\hline $5^{\prime}-\mathrm{OH}$ & & $16.39 \mathrm{~s}$ & & \\
\hline
\end{tabular}


NMR data, see Tables 1 and 2; ESI-MS $m / z 521[\mathrm{M}+\mathrm{Na}]^{+}$, $497[\mathrm{M}-\mathrm{H}]^{-}$; HRFABMS $\mathrm{m} / \mathrm{z} 521.2147$, calculated for $\mathrm{C}_{28} \mathrm{H}_{34} \mathrm{O}_{8} \mathrm{Na}, 521.2151$.

Rezishanone C (3)

Pale yellowish powder; mp 55 56 ${ }^{\circ} \mathrm{C}$; $[\alpha]_{\mathrm{D}}+176^{\circ}(\mathrm{c} 0.7$, $\mathrm{MeOH}), \mathrm{UV}(\mathrm{MeOH}): \lambda_{\max }(\log \varepsilon) 345$ (4.02) nm; CD $(\mathrm{MeOH}) \lambda_{\max }(\Delta \varepsilon) 220(-3.0), 306(-5.6), 351(+1.7) ;{ }^{1} \mathrm{H}$ and ${ }^{13} \mathrm{C}$ NMR data, see Tables 1 and 2; ROESY correlations H-1/C-8, C-13; H-14/C-2'; ESI-MS m/z 321 $[\mathrm{M}+\mathrm{H}]^{+}$; HRESIMS $\mathrm{m} / \mathrm{z}$ 321.1699, calculated for $\mathrm{C}_{18} \mathrm{H}_{25} \mathrm{O}_{5}, 321.1702$.

Rezishanone D (4)

Pale yellowish oil; $[\alpha]_{\mathrm{D}}+197^{\circ}$ (c $\left.0.8, \mathrm{MeOH}\right)$, UV $(\mathrm{MeOH}): \lambda_{\max }(\log \varepsilon) 293(4.04) \mathrm{nm} ; \mathrm{CD}(\mathrm{MeOH}) \lambda_{\max }(\Delta \varepsilon)$ $218(-3.2), 289(-5.3), 361(-1.0) ;{ }^{1} \mathrm{H}$ and ${ }^{13} \mathrm{C}$ NMR data, see Tables 1 and 2; ROESY correlations $\mathrm{H}-1 / \mathrm{C}-8, \mathrm{C}-$ 13, C-1'; H-14/C-2'; ESI-MS m/z $345[\mathrm{M}+\mathrm{Na}]^{+}, 321$ $[\mathrm{M}-\mathrm{H}]^{-}$; HRESIMS $\mathrm{m} / \mathrm{z}$ 323.1865, calculated for

Table $2{ }^{13} \mathrm{C}$ NMR data of compounds $\mathbf{1} \sim \mathbf{4}$.

\begin{tabular}{|c|c|c|c|c|}
\hline No. & 1 & 2 & 3 & 4 \\
\hline 1 & 57.5 & 57.8 & 39.7 & 40.2 \\
\hline 2 & 78.9 & 79.0 & 74.6 & 74.3 \\
\hline 3 & 104.1 & $104.1^{a}$ & 210.9 & 210.9 \\
\hline 4 & 58.8 & 57.4 & 67.0 & 66.6 \\
\hline 5 & 198.0 & 191.4 & 196.4 & 195.0 \\
\hline 6 & 102.7 & 103.3 & 110.4 & 110.3 \\
\hline 7 & 175.9 & 192.8 & 166.4 & 177.4 \\
\hline 8 & 118.5 & 34.7 & 118.0 & 32.2 \\
\hline 9 & 143.6 & 28.2 & 141.8 & 29.2 \\
\hline 10 & 130.9 & 129.0 & 130.9 & 126.8 \\
\hline 11 & 140.4 & 126.4 & 139.2 & 129.0 \\
\hline 12 & 18.7 & 17.8 & 18.8 & 17.8 \\
\hline 13 & 21.3 & 21.2 & 24.3 & 24.4 \\
\hline 14 & 18.9 & 18.6 & 8.9 & 8.8 \\
\hline $1^{\prime}$ & & 57.6 & 30.6 & 30.9 \\
\hline $2^{\prime}$ & & 78.9 & 79.1 & 79.1 \\
\hline $3^{\prime}$ & & $104.2^{a}$ & 65.6 & 65.7 \\
\hline $4^{\prime}$ & & 58.7 & 15.1 & 15.1 \\
\hline $5^{\prime}$ & & 198.3 & & \\
\hline $6^{\prime}$ & & 102.8 & & \\
\hline $7^{\prime}$ & & 176.0 & & \\
\hline $8^{\prime}$ & & 118.4 & & \\
\hline $9^{\prime}$ & & 143.6 & & \\
\hline $10^{\prime}$ & & 130.8 & & \\
\hline $11^{\prime}$ & & 140.4 & & \\
\hline $12^{\prime}$ & & 18.8 & & \\
\hline $13^{\prime}$ & & 21.3 & & \\
\hline $14^{\prime}$ & & 19.1 & & \\
\hline
\end{tabular}

Chemical shifts are shown in the $\delta$ scale; ${ }^{a}$ Interchangeable.
$\mathrm{C}_{18} \mathrm{H}_{27} \mathrm{O}_{5}, 323.1858$.

\section{Structure Determination}

The structures of trichodimerol (1), and rezishanones C (3) and D (4) were identified by spectral data interpretation and comparison with literature values $[5,7,19,20]$. Compound 2 was obtained as an amorphous yellow powder and was shown to possess a molecular formula of $\mathrm{C}_{28} \mathrm{H}_{34} \mathrm{O}_{8}$ by positive HRFABMS. The ${ }^{1} \mathrm{H}$ and ${ }^{13} \mathrm{C}$ NMR spectra of compound 2 displayed the characteristic paired signals including those of trichodimerol (1), suggesting that compound $\mathbf{2}$ is a modified trichodimerol (1) and is based on a bisorbicillinoid skeleton [16, 21]. Thus, the absence of two olefinic methine signals and the presence of two sets of methylene signals at $\delta_{\mathrm{H}} 2.38(1 \mathrm{H}, \mathrm{m}, \mathrm{H}-8), 2.45(1 \mathrm{H}, \mathrm{m}$, $\mathrm{H}-8)$, and 2.27 (2H, m, H-9), and the corresponding carbon signals at $\delta_{\mathrm{C}} 34.7(\mathrm{C}-8)$, and $28.2(\mathrm{C}-9)$, indicated that one of the sorbyl chains of trichodimerol (1) is partially saturated. The position of hydrogenation was confirmed using the HMBC NMR experiment $(\mathrm{H}-8 / \mathrm{C}-7, \mathrm{C}-9$, C10; H-9/C-7, C-8, C-10, C-11; H-10/C-8, C-9, C-11, C-12) (Fig. 2). Therefore, the structure of this new bisorbicillinoid, dihydrotrichodimerol (2), was assigned.

\section{Biological Activities}

All isolated compounds, trichodimerol (1), dihydrotrichodimerol (2), and rezishanones C (3) and D (4), were tested for the ability to activate peroxisome proliferatoractivated receptors using a PPAR-GAL4 chimeric transactivation assay. These four compounds did not activate PPAR $\alpha$ and PPAR $\delta$ up to $10 \mu \mathrm{g} / \mathrm{ml}$. However, dihydrotrichodimerol (2) selectively activated PPAR $\gamma$ with an $\mathrm{ED}_{50}$ value of $80 \mathrm{ng} / \mathrm{ml}$ (Fig 3, A). The maximum activity of dihydrotrichodimerol (2) activating PPAR $\gamma$ was about $75 \%$ of rosiglitazone, a well-known selective PPAR $\gamma$ agonist [22]. Trichodimerol (1) has been reported to inhibit

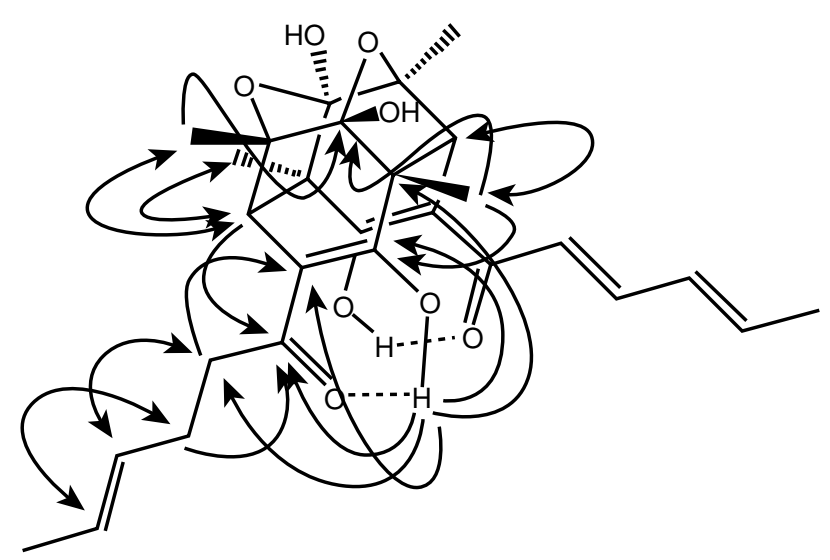

Fig. 2 Selected HMBC correlations of compound 2. 
A

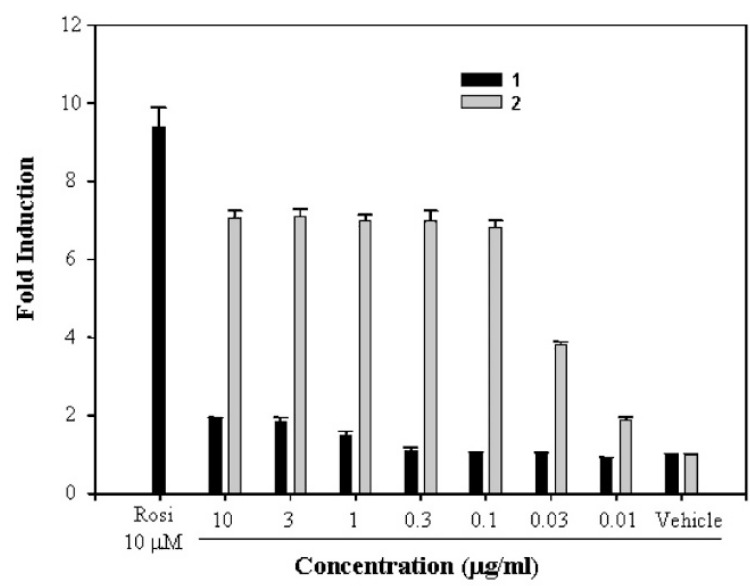

B

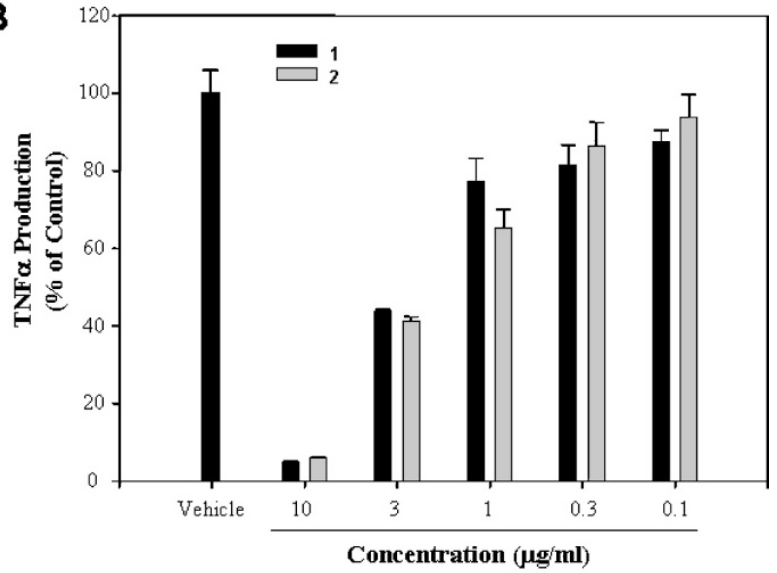

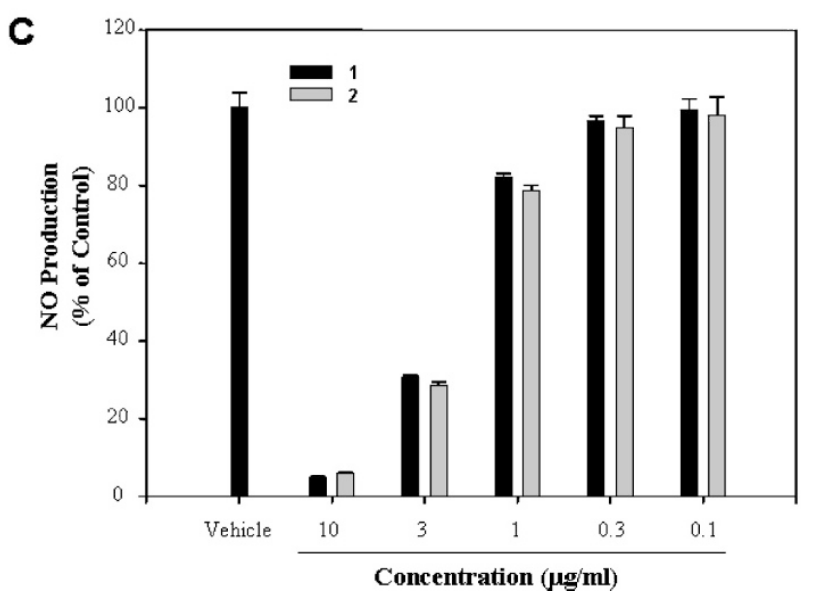

Fig. 3 Effects of compounds $\mathbf{1}$ and $\mathbf{2}$ on the activation of peroxisome proliferator-activated receptor $\gamma(\mathrm{A})$, tumor necrosis factor (TNF)- $\alpha$ production (B), and nitric oxide (NO) production (C).

TNF- $\alpha$ production in LPS-stimulated RAW264.7 cells [11]. Therefore, we compared the effects of compounds 1 and $\mathbf{2}$ on the production of inflammatory mediators, TNF- $\alpha$ and nitric oxide (NO), in LPS-stimulated RAW264.7 cells. As shown in Fig. 3. (B and C), both compounds $\mathbf{1}$ and $\mathbf{2}$ suppressed the production of TNF- $\alpha$ and NO with similar $\mathrm{IC}_{50}$ values. Several reports have suggested that PPAR $\gamma$ ligands such as rosiglitazone and 15-deoxy- $\Delta^{12,14}$ prostaglandin $\mathrm{J}_{2}$ exert their anti-inflammatory activities with a PPAR $\gamma$-independent mechanism in RAW 264.7 cells [22]. In this regard, trichodimerol (1) and dihydrotrichodimerol (2) could exert their antiinflammatory activities independent of PPAR $\gamma$. Therefore, further investigations are necessary to determine the exact mechanism of dihydrotrichodimerol (2) on the PPAR $\gamma$ activation.

Acknowledgements The work was supported by the KRIBB Research Initiative Program and the 21C Frontier Microbial Genomics and Application Center (Grant MG05-
0303-2-0 to Y.-S.H.), the Ministry of Science and Technology, Republic of Korea. Korea Basic Science Institute is thanked for providing certain instruments used in this study.

\section{References}

1. Issemann I, Green S. Activation of a member of the steroid hormone receptor superfamily by peroxisome proliferators. Nature 347: 645-650 (1990)

2. Daynes RA, Jones DC. Emerging roles of PPARs in inflammation and immunity. Nat Rev Immunol 2: 748-759 (2002)

3. Murphy GJ, Holder JC. PPAR- $\gamma$ agonists: therapeutic role in diabetes, inflammation and cancer. Trends Pharmacol Sci 21: 469-474 (2000)

4. Hwang BY, Lee JH, Nam JB, Kim HS, Hong YS, Lee JJ. Two new furanoditerpenes from Saururus chinenesis and their effects on the activation of peroxisome proliferatoractivated receptor $\gamma$. J Nat Prod 65: 616-617 (2002) 
5. Andrade R, Ayer WA, Mebe PP. The metabolites of Trichoderma longibrachiatum. Part 1. Isolation of the metabolites and the structure of trichodimerol. Can J Chem 70: 2526-2535 (1992)

6. Gao Q, Leet JE, Thomas ST, Matson JA, Bancroft DP. Crystal structure of trichodimerol. J Nat Prod 58: 1817-1821 (1995)

7. Maskey RP, Grun-Wollny I, Laatsch H. Sorbicillin analogues and related dimeric compounds from Penicillium notatum. J Nat Prod 68: 865-870 (2005)

8. Abe N, Murata T, Hirota A. Novel DPPH radical scavengers, bisorbicillinol and demethyltrichodimerol, from a fungus. Biosci Biotechnol Biochem 62: 661-666 (1998)

9. Mazzucco CE, Warr G. Trichodimerol (BMS-182123) inhibits lipopolysaccharide-induced eicosanoid secretion in THP-1 human monocytic cells. J Leukocyte Biol 60: 271-277 (1996)

10. Sperry S, Samuels GJ, Crews P. Vertinoid polyketides from the saltwater culture of the fungus Trichoderma longibrachiatum separated from a Haliclona marine sponge. J Org Chem 63: 10011-10014 (1998)

11. Warr GA, Veitch JA, Walsh AW, Hesler GA, Pirnik DM, Leet JE, Lin PF, Medina IA, McBrien KD, Forenza S, Clark JM, Lam KS. BMS-182123, a fungal metabolite that inhibits the production of TNF- $\alpha$ by macrophages and monocytes. J Antibiot 49: 234-240 (1996)

12. Abe N, Arakawa T, Yamamoto K, Hirota A. Biosynthesis of bisorbicillinoid in Trichoderma sp. USF-2690; evidence for the biosynthetic pathway, via sorbicillinol, of sorbicillin, bisorbicillinol, bisorbibutenolide, and bisorbicillinolide. Biosci Biotechnol Biochem 66: 2090-2099 (2002)

13. Abe N, Sugimoto O, Arakawa T, Tanji K, Hirota A. Sorbicillinol, a key intermediate of bisorbicillinoid biosynthesis in Trichoderma sp. USF-2690. Biosci Biotechnol Biochem 65: 2271-2279 (2001)

14. Abe N, Yamamoto K, Arakawa T, Hirota A. The biosynthesis of bisorbicillinoids: evidence for a biosynthetic route from bisorbicillinol to bisorbibutenolide and bisorbicillinolide. Chem Commun: 23-24 (2001)

15. Barnes-Seeman D, Corey EJ. A two-step total synthesis of the natural pentacycle trichodimerol, a novel inhibitor of TNF- $\alpha$ production. Org Lett 1: 1503-1504 (1999)

16. Nicolaou KC, Vassilikogiannakis G, Simonsen KB, Baran PS, Zhong YL, Vidali VP, Pitsinos EN, Couladouros EA. Biomimetic total synthesis of bisorbicillinol, bisorbibutenolide, trichodimerol, and designed analogues of the bisorbicillinoids. J Am Chem Soc 122: 3071-3079 (2000)

17. Forman BM, Tontonoz P, Chen J, Brun RP, Spiegelman BM, Evans RM. 15-Deoxy- $\Delta^{12,14}$-prostaglandin $\mathrm{J}_{2}$ is a ligand for the adipocyte determination factor $\operatorname{PPAR} \gamma$. Cell 83: 803-812 (1995)

18. Lee JH, Koo TH, Hwang BY, Lee JJ. Kaurane diterpene, kamebakaurin, inhibits NF- $\mathrm{KB}$ by directly targeting the DNA-binding activity of p50 and blocks the expression of antiapoptotic NF- $\mathrm{KB}$ target genes. J Biol Chem 277: 18411-18420 (2002)

19. Abe N, Murata T, Hirota A. Novel oxidized sorbicillin dimers with 1,1-diphenyl-2-picryl-radical scavenging activity from a fungus. Biosci Biotechnol Biochem 62: 2120-2126 (1998)

20. Shirota O, Pathak V, Hossain CF, Sekita S, Takatori K, Satake M. Structural elucidation of trichotetronines: polyketides possessing a bicyclo[2.2.2] octane skeleton with a tetronic acid moiety isolated from Trichoderma sp. J Chem Soc Perkin Trans I 1997: 2961-2964 (1997)

21. Trifonov LS, Hilpert H, Floersheim P, Dreiding AS, Rast DM, Skrivanova R, Hoesch L. Bisvertinols: a new group of dimeric vertinoids from Verticillium intertextum. Tetrahedron 42: 3157-3179 (1986)

22. Castrillo A, Mojena M, Hortelano S, Bosca L. Peroxisome proliferator-activated receptor- $\gamma$-independent inhibition of macrophage activation by the non-thiazolidinedione agonist L-796449: Comparison with the effects of 15-deoxy- $\Delta^{12,14}$ prostaglandin $\mathrm{J}_{2}$. J Biol Chem 276: 34082-34088 (2001) 